\title{
RESEARCH
}

Open Access

\section{Effect of nanopolysaccharide (BSEPS) from Bacillus subtilis sp. on thioacetamide- induced liver fibrosis in rats}

\author{
Manal G. Mahmoud ${ }^{1}$, Mohsen S. Asker ${ }^{1}$, Mohamed E. El Awady ${ }^{1}$, Amal I. Hassan ${ }^{2 *}$ (D) Nadia A. R. Zaharan ${ }^{2}$ and
} Hanan F. Youssef ${ }^{3}$

\begin{abstract}
Background: Nanomedicine contributes to the efficiency of pharmacological treatments and progresses rapidly. The present study was designed to produce exopolysaccharide (BSEPS) from Bacillus subtilis sp. strain reported in our previous study was further characterized, and its BSEPS for synthesis of the nanoparticle Ag-BSEPS using microwave heating to determine the possible effects of a prepared solution containing Ag-BSEPS versus thioacetamide (TAA) evoked liver fibrosis in Wister albino rats. Nanoparticles with silver (Ag) core have been synthesized in an aqueous solution after exposure of BSEPS to periodate oxidation. Animals were split into four groups: I - control rats, water ad libitum for 6 weeks; II - rats were injected with TAA 200 mg/ $/ \mathrm{kg}^{-1} 3$ times/week for 4 weeks IP; III - Ag-BSEPS $100 \mathrm{mg} / \mathrm{kg}^{-1}$ IP twice a week for 6 weeks; and IV - TAA, as group II followed by Ag-BSEPS as group III. The antifibrotic effects of Ag-BSEPS were appraised by determining different hepatotoxicity indices, oxidative stress, and inflammatory and liver fibrosis markers.

Results: Nanoparticles were obtained with a diameter size range of 50-100 nm characterized by SEM and TEM without using any harmful reagents. Results evinced considerably reduced activity of liver functions such as transaminases (AST, ALT), gamma-glutamyl transferase (GGT), and alkaline phosphatase (ALP) in the group which received TAA followed by Ag-BSEPS compared to the other group which received only TAA. In the current results, the administration of Ag-BSEPS showed an improvement in the proinflammatory cytokines. On the contrary, the antioxidant enzymes in liver homogenates revealed significant improvement (concentration of glutathione peroxidase (GSH-PX), superoxide dismutase (SOD), and catalase (CAT) increases) in animals with TAA-induced liver damage followed by Ag-BSEPS. Moreover, the activities of the fibrotic markers transforming growth factor-beta 1(TGF- $\beta 1$ ) and type III pro-collagen (PCIII) were increased in liver tissues in the group which was given TAA alone as compared to the controls. The percentage of fibrosis of hepatic tissue had a positive correlation with the levels of PCIII and TGF- $\beta 1$, followed by Ag-BSEPS compared to the TAA group without nanocomposite treatment. Microscopic examinations revealed inhibitory effects of Ag-BSEPS on inflammatory changes and deterrent of liver fibrosis.
\end{abstract}

Conclusion: It was suggested that the biochemical and histological amelioration observed in Ag-BSEPS $\left(100 \mathrm{mg} / \mathrm{kg}^{-1}\right.$ twice a week for 6 weeks) treated the fibrotic rats.

Keywords: Nanopolysaccharide, Nanomedicine, Thioacetamide, Fibrosis, Cytokines

\footnotetext{
* Correspondence: virtualaml@gmail.com

${ }^{2}$ Department of Radioisotopes, Atomic Energy Authority, Nuclear Research

Centre, Cairo, Egypt

Full list of author information is available at the end of the article
} 


\section{Background}

Fibrosis is characterized by an abundance of collagen because of a new fiber construction that causes some clinical indications influence liver functions associated with pathological abnormalities (Anthony et al. 1978; AlAttar and Al-Rethea 2017).

The advancement of liver fibrosis, thusly bringing about cirrhosis, is inferable from different etiological elements, including hepatic infections from viruses, along with drugs and immune system morbidness like autoimmune diseases, and hereditary issue, for example, Wilson ailment (copper participates in liver cells) or haemochromatosis (iron participates in liver) (Bataller and Brenner 2005).

Thioacetamide (TAA) is considered as one of the organosulfur compounds which are conceivable hepatocarcinogens dependent on the adequate confirmations in the experiential animals (Iravani et al. 2014; Czechowska et al. 2015).

The ideal agent, which causes fibroid degeneration, that is safe used over a protracted time, specific to the liver and nontoxic to hepatocytes, potentially pharmaceutically effective, and orally bioavailable, is not obtainable so far. Substantiation of these agents with longterm advantages that can mitigate clinical consequences, such as portal hypertension, and prevent development the fibrosis to cancer is needed (Friedman et al. 2008; Al-Attar and Al-Rethea 2017).

However, although the noninvasive approaches within the diagnosing of fibrosis are still evolving, it is promising (Ismail and Pinzani 2009). It is visualized that fabrication of nanoparticles can enable specifically decisive targeting cell varieties of the diseased organ and delivering competent anti-inflammatory or anti-fibrotic medicine with minimum undesirable side effects. NPs with a diameter of less than two hundred nanometers show prolonged blood circulation and a comparatively low rate of reticuloendothelial system (RES) uptake (Giannitrapani et al. 2014).

Our understanding of fibrosis syndrome has been significantly modified over the past decade; it has become a dynamic process that needs a lot of research to target a safe therapy. Thus, the realization that fibrosis can recede gives new importunity to the investigations (Wenshan et al. 2018).

This study was conducted to prepare the nanoparticle Ag-BSEPS, investigate its characterization by scanning electron microscope (SEM) and transmission electron microscope (TEM), and evaluate the potential effectivity of Ag-BSEPS nanoparticle as an antifibrotic cure in thioacetamide-induced liver fibrosis in an animal model. Furthermore, its potentiality to prohibit the aggravation of liver cirrhosis and its effective ability to invert the undesirable symptoms that require liver transplantation as a preventive measure of liver access to cirrhosis and cancer are also examined.

\section{Materials and methods}

Bacillus subtilis produced BSEPS, and its partial chemical structure was described in our previous study (Ghoneim et al. 2016).

\section{Synthesis of nanoparticles}

BSEPS was obtained from Bacillus subtilis sp. Nanoparticles with silver $(\mathrm{Ag})$ core have been synthesized in an aqueous solution (Ying et al. 2005). These methods provide a water-dispersible nanoparticle which is necessary for the application in biological systems. The aqueous solution has been made from polyaldehyde-BSEPS. Polyaldehyde-BSEPS was prepared by the periodate oxidation method (Allene and Wilham 1950). BSEPS (10 g) was dissolved under stirring in $200 \mathrm{ml}$ of distilled water. Then, 2.3 g sodium metaperiodate was added; the reaction was carried on in darkness at $24{ }^{\circ} \mathrm{C}$ for $1 \mathrm{~h}$ and the reaction was stopped by $1 \mathrm{ml}$ ethylene glycol. The oxidized BSEPS solution was dialyzed against distilled water (dialysis bag $3 \mathrm{kDa}$ cut off), the dialyzed solution was lyophilized. The degree of oxidation was determined by Hydroxylamine hydrochloride (Huiru and Heindel 1991). The BSEPS-based nanoparticles were synthesized as follows: polyaldehyde-BSEPS was dissolved in $10 \mathrm{ml}$ of deionized water to reach the desired concentration and added $100 \mu \mathrm{l}$ of $\mathrm{AgNO}_{3}$ solution (0.1 M). This mixture $(20 \mathrm{ml}$ of a prepared solution) was loaded into the microwave hydrothermal treatments $(\mathrm{M}-\mathrm{H}), 100 \mathrm{ml}$ capacity Xpress vessels of microwave digestion system, Mars 5, Model XP-1500, CEM Corp., Matthews, NC. The system operates at a frequency of $2.45 \mathrm{GHz}$ and can operate at $1-100 \%$ of $1600 \mathrm{~W}$ power and heat-treated for $30 \mathrm{~min}$ at $70{ }^{\circ} \mathrm{C}$. The synthetic product is then collected, and the solution of Ag nanoparticles was centrifuged 15,000 $\mathrm{rpm}$ for $5 \mathrm{~min}$ and re-suspended in deionized water, washed several times with deionized water to remove the excess BSEPS. The final Ag nanoparticles were re-suspended in deionized water and became ready for different characterization (Ag-BSEPS).

The properties of the nanoparticles were determined using an ultraviolet-visible (UV-Vis) absorption spectrum (2401PC; Shimadzu, Kyoto, Japan) and transmission (TEM) and scanning (SEM) electron microscopes (JEOL, JEM-2100, Japan) to observe the morphology of the AgBSEPS nanoparticles.

\section{Animals}

Thirty-two adult male Sprague-Dawley rats, 8 weeks old, weighing about $160 \pm 10 \mathrm{~g}$, were purchased from the laboratory animal colony at the Institute of Ophthalmology, Cairo University, Egypt. Rats were maintained 
under standard conditions of temperature $\left(25^{\circ} \mathrm{C}\right)$ with a 12- (light) to 12 -h (dark) cycle and were allowed free access to standard laboratory food and water. The experimental protocol conducted in the study complies with the ethical guidelines and the principles for the care, use, and handling of experimental animals adopted by the Research Ethics Committee, of the National Research Centre in Egypt. The adopted guidelines are following the Guide for the Care and Use of Laboratory Animals ILAR (Institute of Laboratory Animal Resources) (1985). The study protocol was approved by members of The Research Ethics Committee, of the National Research Centre in Egypt.

\section{Chemicals}

Thioacetamide was purchased from Sigma Chemicals Co. (St. Louis, Missouri, USA) and was dissolved in $0.9 \%$ $w / v$ saline solution for intraperitoneal injection.

\section{Study design}

Study of the potential ability of Ag-BSEPS was preventing the progression of liver fibrosis in TAA-injected rats. Rats were randomly divided into four groups (8 rats): Group 1, control; Group II, liver fibrosis was induced in Sprague-Dawley rats by IP injection of TAA $(200 \mathrm{mg} /$ $\mathrm{kg}^{-1}$ body mass), 3 times/week (Nakajima et al. 1998) for 4 weeks; Group III, the nano-Ag-BSEPS-treated group, where rats received Ag-BSEPS (100 mg/kg, IP) twice a week for 6 weeks; Group IV was treated with Ag-BSEPS after $24 \mathrm{~h}$ following the last injection of TAA at a daily dose of $100 \mathrm{mg} / \mathrm{kg}$. Rat body mass was recorded 2 times/week, and average alteration in body mass was calculated at the end of the experimental period. After 6 weeks of the treatment, the animals were sacrificed. Blood samples were collected from the animals under light ether anesthesia, and then the serum was separated and used for immediate determination of the biochemical parameters. Livers of all of the rats were removed, weighed to calculate liver / body weight, and then rinsed in an ice-cold saline solution for histopathological examination and estimation of liver parameters. A portion of the liver was harvested, of which, $100 \mathrm{mg}$ was weighed and kept in $0.5 \% \mathrm{KCl}$ for estimation of liver antioxidant enzymes, proinflammatory cytokines, and liver fibrosis markers such as type III pro-collagen (PCIII), transforming growth factor-beta 1 (TGF- $\beta 1$ ), and collagen type.

\section{Measurement of biochemical parameters}

Measurement of serum ALT, AST, bilirubin, ALP, albu$\mathrm{min}$, and GGT in blood samples were collected from the rats under anesthesia in clean, dry Wassermann tubes by puncture of the retro-orbital plexus using heparinized capillary tubes. The samples were allowed to stand for $15 \mathrm{~min}$ to clot at room temperature and then centrifuged $(400 \times g$ for $10 \mathrm{~min})$. The serum was collected and used immediately for the determination of serum ALT, AST, ALP, and albumin, using a Biomerieux kit (France), total bilirubin using a Biocon kit (Biocon Diagnostik, Germany), and GGT (Fortress Diagnostics, Ltd., UK). Estimation of lipid peroxidation (TBARS) assay was carried out by following the method of Ohkawa et al. (1979).

\section{Measurement of fibrosis markers in liver tissue TGF-1 $\beta$, collagen IV, and PCIII}

Using ELISA assay kits were obtained from $\mathrm{R}$ and $\mathrm{D}$ (USA). Absorbance was measured at the specified wavelengths. Test procedures were carried out according to the manufacturer's instructions. This assay employs an antibody specific for rat TGF- $\beta 1$, collagen IV, and PCIII coated on a 96-well plate. Standards and samples are pipetted into the wells and TGF- $\beta 1$, collagen IV, and PCIII present in a sample is bound to the wells by the immobilized antibody. The wells are washed and biotinylated anti-TGF- $\beta 1$ or anti-PCIII antibodies are added. After washing away unbound biotinylated antibody, HRPconjugated streptavidin is pipetted to the wells. The wells are again washed, a TMB substrate solution is added to the wells and color develops in proportion to the amount of TGF- $\beta 1$ bound and PCIII. The stop solution changes the color from blue to yellow, and the intensity of the color is measured at $450 \mathrm{~nm}$.

\section{Cytokines in liver tissue}

IL1 $\beta$, IL6, IL 10, and INF- $\gamma$ were measured in the liver using a BCA kit (Pierce, Rockford, IL) according to the manufacturer's instructions. Briefly, each kit had a specific microplate pre-coated with a monoclonal antibody against its analyte. After adding the standards and samples, the analyte was sandwiched by the immobilized antibody and a biotinylated polyclonal antibody specific for it. The later was recognized by a streptavidin-peroxidase conjugate. Unbound materials were then washed away. Thereafter, a peroxidase enzyme substrate was added followed by the stop solution. Finally, color intensity was determined at $450 \mathrm{~nm}$ using a microplate reader (ChroMate-4300, USA).

\section{Antioxidant enzymes in liver tissue}

The catalase (CAT), glutathione peroxidase GSH-PX, and superoxide dismutase (SOD) enzyme activities in the tissues were assayed following the procedure of Sinha (1972), Rotruck et al. (1973), and Kakkar et al. (1999), respectively. Homogenate $(0.1 \mathrm{ml})$ was incubated with $\mathrm{H}_{2} \mathrm{O}_{2}(0.2 \mathrm{M}, 0.5 \mathrm{ml})$, in the existence of $0.01 \mathrm{M}$ phosphate buffer ( $\mathrm{pH} 7.4$ ). Afterward, 5\% dichromate solution was added, the reaction was stopped. After that, CAT samples were incubated in boiling water for 15 
min. The absorbance of the upper layer of the mixture was read at $570 \mathrm{~nm}$. GSH-PX activity was assayed by the method of Rotruck et al. (1973) using $\mathrm{H}_{2} \mathrm{O}_{2}$ as a substrate. The reaction mixture consisted of $1.49 \mathrm{ml}$ phosphate buffer $(0.1 \mathrm{M}, \mathrm{pH} 7.4), 0.1 \mathrm{ml}$ sodium azide (1 $\mathrm{mM}), 0.05 \mathrm{ml}$ glutathione reductase $(1 \mathrm{IU} / \mathrm{ml}), 0.05 \mathrm{ml}$ GSH $(1 \mathrm{mM}), 0.1 \mathrm{ml}$ EDTA $(1 \mathrm{mM}), 0.1 \mathrm{~mL} \mathrm{NADPH}$ $(0.2 \mathrm{mM}), 0.01 \mathrm{ml} \mathrm{H}_{2} \mathrm{O}_{2}(0.25 \mathrm{mM})$, and $0.1 \mathrm{ml} 10 \%$ homogenate in a total volume of $2 \mathrm{ml}$. The discoloration of NADPH at $340 \mathrm{~nm}$ was recorded at $25^{\circ} \mathrm{C}$; the enzyme activity was calculated as $\mathrm{U} / \mathrm{mg}$ of protein. In the measuring of SOD, the reaction mixture of this method contained $0.1 \mathrm{ml}$ of phenazine methosulphate $(186 \mu \mathrm{M}), 1.2$ $\mathrm{ml}$ of sodium pyrophosphate buffer $(0.05 \mathrm{mM}, \mathrm{pH} 7.0)$, $0.3 \mathrm{ml}$ of supernatant after centrifugation $(1500 \times g, 10$ min followed by $10,000 \times g, 15 \mathrm{~min}$ ) of $10 \%$ homogenate was added to the reaction mixture. The enzyme reaction was initiated by adding $0.2 \mathrm{ml}$ of NADH $(780 \mu \mathrm{M})$ and stopped after 1 min by adding $1 \mathrm{ml}$ of glacial acetic acid. The changes in the absorbance were measured at 560 $\mathrm{nm}$ using the spectrophotometer. Results are expressed in units/mg protein.

\section{Determination of VEGF levels}

The levels of VEGF of the liver were determined by a commercially available ELISA kit ( $\mathrm{R}$ and D Systems), according to the manufacturer's instructions (Werther et al. 2002).

\section{DNA extraction}

For each sample to be processed, $120 \mu \mathrm{l}$ of a $0.5-\mathrm{M}$ EDTA solution ( $\mathrm{pH}$ 8.0) was added to $500 \mu \mathrm{l}$ of Nuclei Lysis Solution in a centrifuge tube and chilled on ice. A fresh or thawed stool $(0.5$ to $1 \mathrm{~cm})$ was added to a 1.5 $\mathrm{ml}$ microcentrifuge tube. Six hundred microliters of the EDTA/Nuclei Lysis Solution was added to the tube followed by $17.5 \mu \mathrm{l}$ of $20 \mathrm{mg} / \mathrm{ml}$ Proteinase $\mathrm{K}$, and the mixture was then incubated overnight at $55{ }^{\circ} \mathrm{C}$ with gentle shaking. Three microliters of RNase was added to the nuclear lysate, and the sample was mixed by inverting the tube 2-5 times. The mixture was incubated for 1530 minutes at $37^{\circ} \mathrm{C}$ and then allowed to cool to room temperature for $5 \mathrm{~min}$ before proceeding. Two hundred microliters of protein precipitation solution was then added and vortexed vigorously at high speed for $20 \mathrm{~s}$, and then the sample was chilled on ice for $5 \mathrm{~min}$. The sample was centrifuged for $4 \mathrm{~min}$ at $15,000 \times g$, and the supernatant containing the DNA was removed and transferred to a clean 1.5-microcentrifuge tube containing $600 \mu \mathrm{l}$ of room temperature isopropanol. The solution was gently mixed by inversion until the white thread-like strands of DNA formed a visible mass and was then centrifuged for $1 \mathrm{~min}$ at $15,000 \times g$ at room temperature. The supernatant was then decanted. Six hundred microliters of room temperature $70 \%$ ethanol was added, and the tube was gently inverted several times to wash the DNA. It was centrifuged for $1 \mathrm{~min}$ at $15,000 \times g$ at room temperature. The ethanol was then aspirated using a sequencing pipette tip, and the tube was inverted on clean absorbent paper and the pellet was air-dried for 10-15 min. One hundred microliters of DNA Rehydration Solution was then added and the DNA was rehydrated by incubating at $65{ }^{\circ} \mathrm{C}$ for $1 \mathrm{~h}$. The solution was periodically mixed by gently tapping the tube. The DNA was stored at $2-8{ }^{\circ} \mathrm{C}$. The extracted DNA was measured by spectrophotometer at $260 \mathrm{~nm}$ to detect its concentration.

\section{Agarose gel electrophoresis for DNA fragmentation}

DNA was isolated from rat livers. Then $2 \%$ agarose gel was prepared as follows: $1 \mathrm{~g}$ of agarose was dissolved in $50 \mathrm{ml}$ of Tris-Acetate EDTA buffer (TAE) buffer in a flask covered with aluminum foil for $5 \mathrm{~min}$ in a microwave adjustable to medium temperature. When the agarose solution cooled to $60{ }^{\circ} \mathrm{C}, 2.5 \mu \mathrm{l}$ of ethidium bromide (EB) was added to allow subsequent visualization of the DNA. Gloves were used when working with solutions containing EB dye because it is a powerful mutagen and is moderately toxic. The gel was poured into a clean and dry gel mold. When the agarose had set completely (20$30 \mathrm{~min}$ ), the comb was carefully removed, and the gel was placed in the electrophoresis chamber. The sample wells were positioned at the negative electrode end of the gel tank so that DNA migrates through the gel towards the positive electrode. An amount of TAE buffer was added to sufficiently cover the gel. For loading the gel, $9 \mu \mathrm{l}$ from the second amplified DNA was added with $3 \mu \mathrm{l}$ of loading dye in a $0.5-\mathrm{ml}$ Eppendorf tube. Samples were loaded carefully into the wells without hitting the gel to avoid diffusion. The gel control marker was also loaded to determine the size of the PCR product. A 5- $\mu$ l marker and a 3- $\mu$ l loading dye were used. The lid of the electrophoresis chamber was closed, the gel run at 100 V, 250 A for $20 \mathrm{~min}$. After electrophoresis, the gel was studied under a gel doc system and was photographed with a digital camera.

\section{Histopathology}

Livers from all of the animals were harvested and rinsed in an ice-cold saline solution. The left lobe was then separated and fixed in 10\% neutral buffered formalin solution. Specimens were embedded in paraffin and sectioned (4- $\mathrm{m}$ thick) by a specialized histopathological technician. The slides were stained with hematoxylin and eosin ( $\mathrm{H}$ and $\mathrm{E})$. The prepared tissue slides were then examined under a microscope in random order to assess the histopathological changes in $\mathrm{H}$ and E-stained slides (Banchroft et al. 1996). 


\section{Statistical examination}

The data obtained from the experimental groups were analyzed as the means \pm standard errors of the means. The differences between the groups were analyzed using the one-way of variance analysis (ANOVA) followed by the Tukey-Kramer multiple range comparison tests. The data were considered statistically significant when the values were less than 0.05 .

\section{Results}

The EPS production by Bacillus subtilis $s p$. was found to be consistent and has been used in an antecedent study (Ghoneim et al. 2016). Our previous study of the initial description of the extracted EPS by chemical analysis, FT-IR spectroscopy, and HPLC showed the presence of uric acid groups, with an indication of BSEPS component-like polymer (Ghoneim et al. 2016). The color of the suspension was changed from white to dark violet when the reaction was performed, and these colors appear due to Plasmon absorbance. The maximum absorbance and the color of the solution are according to the size of nanoparticles. This observation has been confirmed by UV-Vis absorbance spectra which are shown in Fig. 1. While the long chain of BSEPS was adsorbed at the surface of a silver core, BSEPS oxidation impacted on nanoparticle diameter has also been confirmed by SEM and TEM. Results showed that the employment of polyaldehyde-BSEPS increases nanoparticle diameter.

Figure $2 \mathrm{a}, \mathrm{b}$ is showing the microstructures of the biocomposites of nanosilver-polyaldehyde-BSEPS composite, heated under microwave conditions of $70{ }^{\circ} \mathrm{C}$ for 30 min. The SEM micrograph (Fig. 2a) implies a homogeneous structure made up of edgy to spot-like, highlighted crystals of nanosilver with a uniform distribution and particle size range of 50-100 nm, embedded in gelicolous matrix full of some elliptical and fibroid structures. Figure 2b implies the TEM microstructure ascertains the previous SEM texture, where the nanosilver particles are showing minute and even distributed black spots of Ag scattered all over the biocomposite of a more lighted colored matrix of the polyaldehydeBSEPS nanoparticle.

The clear even spreading of the Ag nanoparticles within the biocomposite indicated a uniform process of the pretreatment of the polysaccharide oxidation, led to an evenly distributed linkage of $\mathrm{Ag}-\mathrm{CHO}$ within the material.

This study also examines the possibility of Ag-BSEPS to curb the progression of liver fibrosis in rats injected with TAA. Administration of Ag-BSEPS $\left(100 \mathrm{mg} / \mathrm{kg}^{-1}\right.$ IP) doubly every week for 6 weeks fulfilled significant refinement weight gain as compared to the fibrotic rats (Fig. 3 and Table 1). The proportion of liver weight and body mass was remarkably $(p<0.05)$ decreased in comparison to the fibrotic rats' control (Table 1). As shown in Fig. 4, liver function indicators like serums ALT, AST, and ALP and total bilirubin $(p<0.05)$ significantly increased in the fibrotic rats when compared to the controls (Fig. 4a), but serum total protein, albumin, globulin, and GGT were $(p<0.05)$ significantly decreased in comparison with the control rats (Fig. 4b). On the contrary, the antioxidant enzymes in liver tissues were significantly decreased in the fibrotic rats compared to the controls (Fig. 4c). The lucid improvement in serum biochemical parameters after administration on Ag-BSEPS was uphold attended by a notable diminishing in hepatic PCIII, TGF- $\beta$, and lipid peroxidation (TBARS, Table 2). This downgrading was accompanied by a significant reduction in the levels of the proinflammatory cytokines (IL6, IL $1 \beta$, and TNF- $\alpha$ ) compared to the fibrotic control. On the contrary, Ag-BSEPS induced a significant increase of IFN- $\gamma$ and anti-inflammatory cytokine (IL10) compared to fibrotic rats (Table 3).

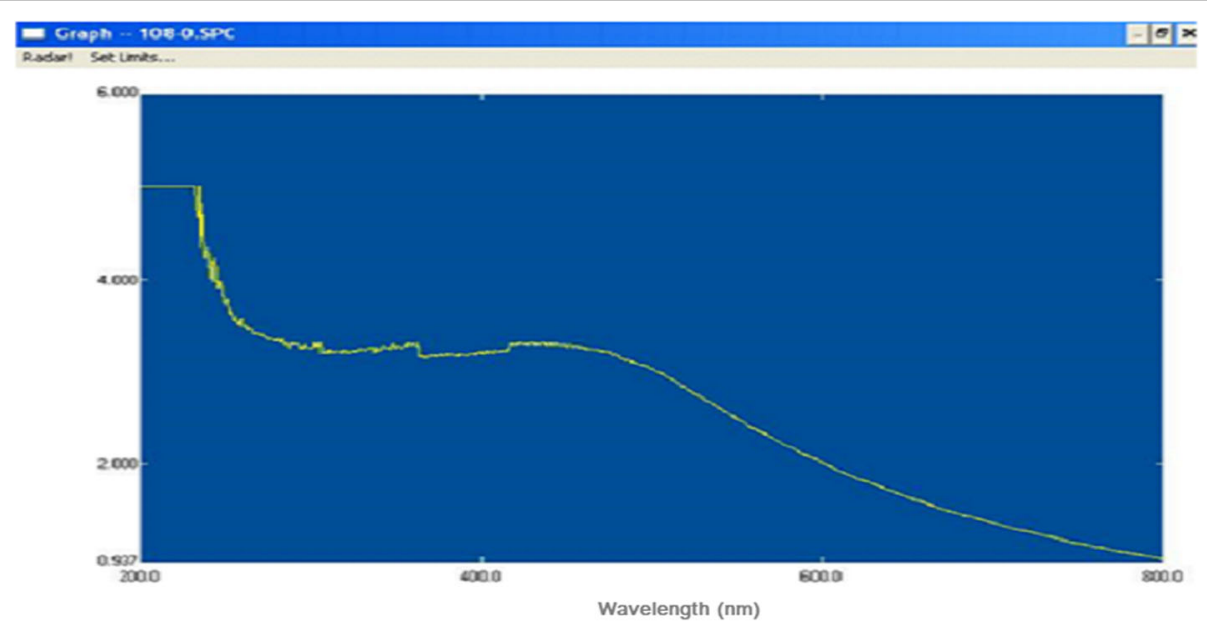

Fig. 1 UV-Vis absorbance spectra for nanocomposite. The long chain of BSEPS was adsorbed at the surface of a silver core. 

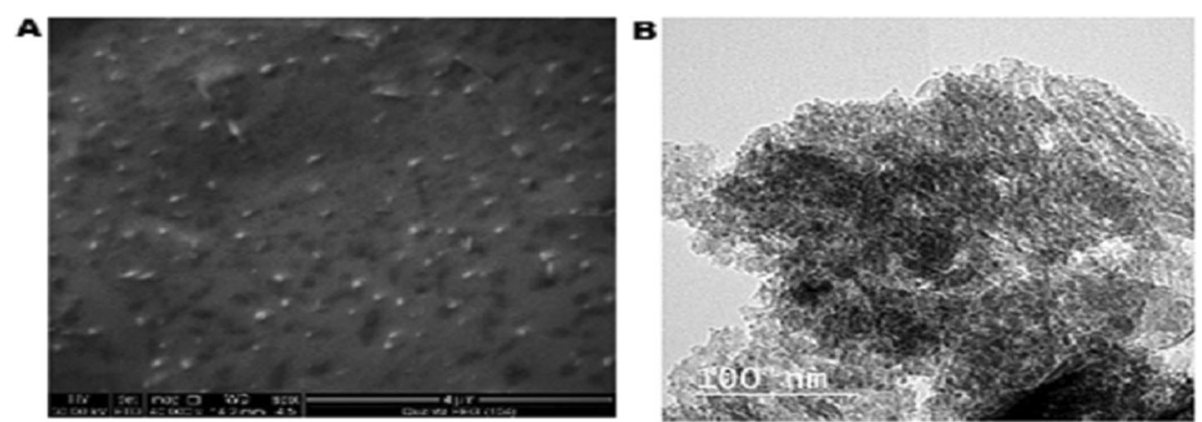

Fig. 2 Microstructure of silver-polyaldehyde-BSEPS composite prepared by microwave technique. (a) SEM, implies a homogeneous structure made up of edgy to spot-like, highlighted crystals of nanosilver with a uniform distribution and particle size range of 50-100 nm; (b) TEM, where the nanosilver particles are showing minute and even distributed black spots of Ag scattered all over the biocomposite of a more lighted colored matrix of the polyaldehyde-BSEPS nanoparticle

Furthermore, TAA caused a significant increase in collagen IV and VEGF, but the administration of nano-AgBSEPS revealed a decrease in the incidence of collagen and VEGF (Fig. 4d and e).

\section{Genotoxicity studies}

Injection of TAA evoked the hepatic DNA damages (fragmentation \%), and treatment of rats with Ag-BSEPS 100 $\mathrm{mg} / \mathrm{kg}$ was restored (Fig. 5). The DNA ladder showed correspondence to the DNA fragmentation assay (Fig. 5).

\section{Histopathological findings}

All of the investigated liver tissue specimens, either from the control groups and/or nano-Ag-BSEPS, were detected with healthy liver tissue with sound parenchyma and wellfunctioning hepatocytes with no evidence of inflammation or fibrosis (Fig. 6a and b). Besides the massive fibrosis, the fatty change was detected in the hepatocytes at the centrilobular area of the parenchyma surrounding the central vein, and degeneration of the hepatocytes and necrosis were also observed in specimens of the fibrotic rats (Fig. 6c and d). Regression in periductal fibrosis and degradation of hepatocytes were also observed with nano-Ag-BSEPS treatment; the examined histopathological specimens from the nano-Ag-BSEPS-treated group attained lower fibrosis grades compared to the fibrotic control group (Fig. $6 \mathrm{f}-\mathrm{h}$ and Table $4)$.

\section{Discussion}

Microwave hydrothermal treatment is an effective heating tool in chemical synthesis with saving of energy and time and cost reduction. Several authors detected that heating is volumetric and penetration and distribution are done quickly and homogeneously to influence the reactive materials and prefer the early and simultaneous nucleation of the microcrystals with the distribution of narrow particle size (Sathupunya et al. 2004; Youssef et al. 2008). On the other hand, conventional heating resulted in crystals of different sizes due to the slow rise in temperature, which allowed the nucleation to continue throughout the reaction period (Sathupunya et al. 2003).

The consequences of this work asserted that the peritoneal injection of Ag-BSEPS ( $100 \mathrm{mg} / \mathrm{kg}$ body mass two times a week) successfully ameliorated the deteriorated liver

\section{Body weight}

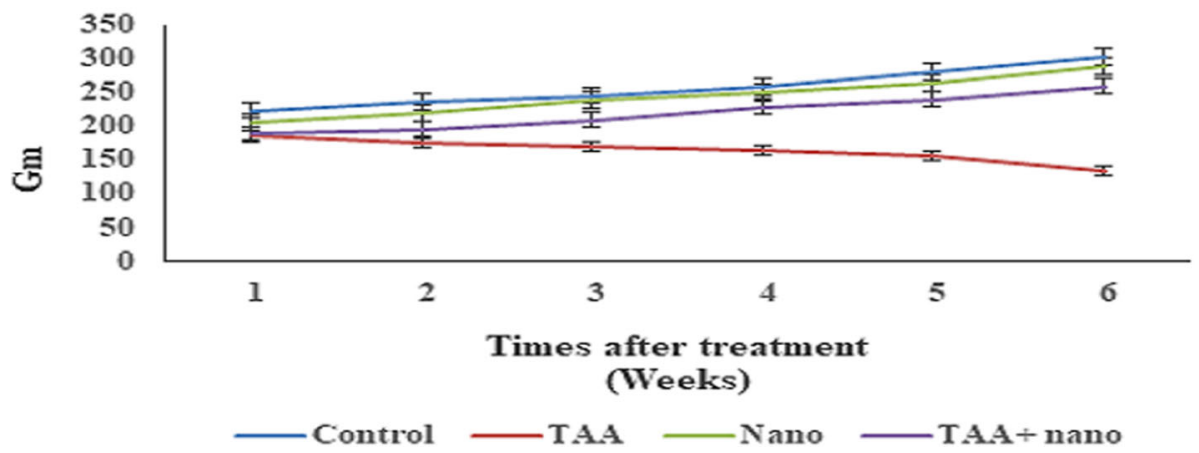

Fig. 3 The body weights before and after and the treatment with Ag-BSEPS in rats 
Table 1 Effect of Ag-BSEPS on body and liver weight before and after treatment

\begin{tabular}{llll}
\hline Groups & Final body weight (g) & Liver weight $(\mathrm{g})$ & Liver weight / Body weight (g) \\
\hline Control (GI) & $304.60 \pm 13.44^{\mathrm{a}}$ & $5.44 \pm 0.56^{\mathrm{b}}$ & $0.016 \pm 0.05^{\mathrm{b}}$ \\
Ag-BSEPS (GII) & $294.96 \pm 10.56^{\mathrm{b}}$ & $5.50 \pm 0.68^{\mathrm{a}}$ & $0.06 \pm 1.23^{\mathrm{a}}$ \\
TAA (GIII) & $135.34 \pm 11.22^{\mathrm{a}}$ & $8.31 \pm 0.46^{\mathrm{b}}$ & $0.02 \pm 0.72^{\mathrm{b}}$ \\
TAA + Ag-BSEPS (GIV) & $280.20 \pm 8.98^{\mathrm{a}}$ & $6.08 \pm 0.52^{\mathrm{b}}$ & $0.02 \pm 0.84^{\mathrm{b}}$ \\
\hline
\end{tabular}

Values are expressed as mean \pm SE. Different superscript letters in the same row indicate significant differences at $p<0.05$.

functions noticed, induced chemically by TAA and engendered hepatic fibrosis in rats. It lowered the proportional indices of liver weight and body weight, reduced the high level of liver functions in the serum (ALT, AST, total bilirubin, and ALP), except serum albumin level since it was increased. The observed amelioration of the serum biochemical parameters was adjoined with a significant lowering in hepatic PCIII content and TGF- $\beta 1$ levels. Comprehensively, the observed provides manifestations of the potential curative avail of the Ag-BSEPS as an anti-fibrotic treatment. The comradeship between the betterment in serological parameters and the diminution in hepatic collagen levels incidence were noticed as well. Ancillary evidence was proven by histopathological scrutiny of the liver tissues and the retrogression of fibrositis through $\mathrm{Ag}$ BSEPS treatment. According to many studies, TAA causes liver fibrosis and cirrhosis, such as series of consequences associated with hepatitis $\mathrm{C}$ in humans (Chu et al. 2006; Kawai et al. 2009; Guerra et al. 2010; Yanguas et al. 2016). TGF- $\beta$ is considered to be one of the most important pre-
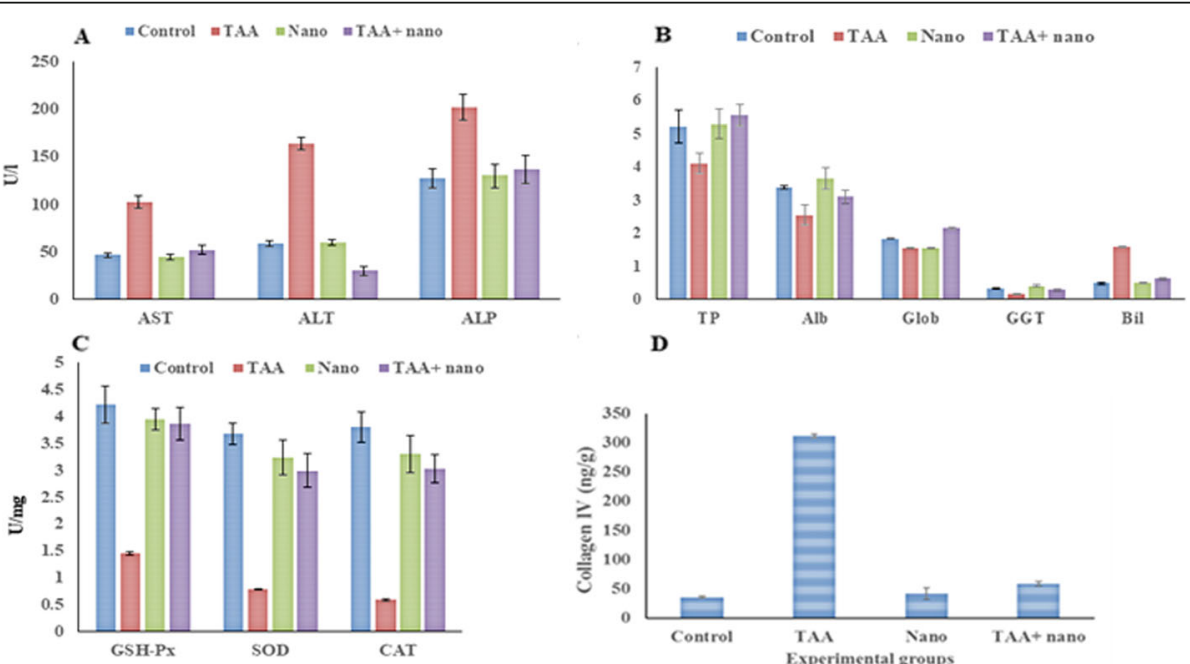

D
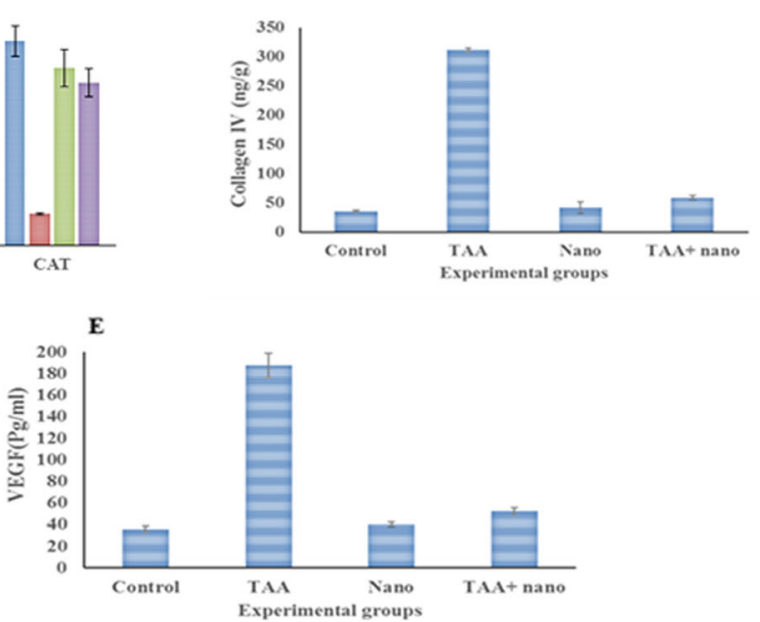

Fig. 4 a Effect of Ag-BSEPS on the liver functions in fibrotic rats. ALT, AST, and ALP before and after treatment with Ag-BSEPS. One-way of variance analysis (ANOVA) followed by the Tukey-Kramer multiple range comparison tests. Data shown are mean \pm S.E.M. and represent the significance of difference, $p<0.05$. $\mathbf{b}$ Effect of Ag-BSEPS on the total protein (TP), albumin (Alb), globulin (Glob), GGT, and bilirubin (Bil) in fibrotic and treated rats. One-way ANOVA followed by the Tukey-Kramer multiple range comparison tests. Data shown are mean \pm S.E.M. and represent the significance of difference, $p<0.05$. c Effect of Ag-BSEPS on the liver antioxidant enzymes in fibrotic and treated rats. One-way ANOVA followed by the Tukey-Kramer multiple range comparison tests. Data shown are mean \pm S.E.M. and represent the significance of difference, $p<$ 0.05. $\mathbf{d}$ Effect of Ag-BSEPS on the collagen IV in fibrotic rats. One-way ANOVA followed by the Tukey-Kramer multiple range comparison tests. Data shown are mean \pm S.E.M. and represent the significance of difference, $p<0.05$. e Effect of Ag-BSEPS on the VEGF in fibrotic rats. One-way ANOVA followed by the Tukey-Kramer multiple range comparison tests. Data shown are mean \pm S.E.M. and represent the significance of difference, $p<0.05$. 
Table 2 Effect of Ag-BSEPS on some of fibrotic markers, and TBARS in control and experimental rats

\begin{tabular}{llll}
\hline Groups & TGF- $\beta$ (ng/gm) & PCIII (pg/gm) & TBARS (nmol/ml) \\
\hline Control (GI) & $1.77 \pm 0.02^{\mathrm{b}}$ & $68.75 \pm 7.81^{\mathrm{b}}$ & $31.65 \pm 1.93^{\mathrm{b}}$ \\
TAA (GII) & $8.40 \pm 0.53^{\mathrm{a}}$ & $189.23 \pm 11.23^{\mathrm{a}}$ & $69.72 \pm 3.23^{\mathrm{a}}$ \\
Ag-BSEPS (GIII) & $1.63 \pm 0.02^{\mathrm{b}}$ & $66.25 \pm 4.78^{\mathrm{b}}$ & $34.01 \pm 2.88^{\mathrm{b}}$ \\
TAA + Ag-BSEPS (GIV) & $2.22 \pm 0.03^{\mathrm{b}}$ & $74.75 \pm 8.79^{\mathrm{b}}$ & $38.51 \pm 2.55^{\mathrm{b}}$ \\
\hline
\end{tabular}

Values are expressed as mean \pm SE. Different superscript letters in the same row indicate significant differences at $p<0.05$.

fibrosis factors that arise from the Kupffer cells and endothelial cells. These factors are responsible for increasing collagen synthesis 1,3 , and 4; therefore, increased expression of such factors is common in cases of the fibrosis and the necrosis accompanied by inflammation, it plays an important role in the fibrogenesis (Chobert et al. 2012; Abdelazim et al. 2015). Our results regarding the effects of Ag-BSEPS administration revealed significantly reduced concentrations of TNF- $\alpha$, IL- 6 , IL- $1 \beta$, and TGF- $\beta$, compared to the TAA group. On the other hand, the increase in the total protein level caused by TAA was further accentuated by Ag-BSEPS. Recently, major attention has been centered on polysaccharides from marine organisms because of their structural and purposeful diversity besides its natural supply of compounds (Gutierrez et al. 2012; Ruocco et al. 2016). Our results demonstrate that BSEPS nanoparticle suppressed pro-inflammatory cytokine production together with attenuate hepatic TNF- $\alpha$, IL-1 $\beta$, and IL-6. These results manifest that the anti-fibrotic impact of Ag-BSEPS may be mediated through inflammation repression.

A clear increase in the amount of collagen was noted in the TAA-induced liver fibrosis, as well as focal necrosis, fatty infiltration, and signs of inflammation. Furthermore, such markers of collagen metabolism as the activities of liver / body weight and the levels of GGT were also significantly above the control values after injection of TAA. On the other hand, Ag-BSEPS administered simultaneously with TAA was able to normalize these previous parameters almost entirely.

In the present work, antioxidant enzyme levels in the TAA rather considerably decreased $(p<0.05)$, while, lipid peroxidation represented by measuring the level of TBARS increased in contrast with the control group $(p<$ 0.05). There was a contraindication in the event after the use of Ag-BSEPS, the TBARS levels were adjusted to the normal rates. Ag-BSEP-treated rats have eliminated from the adverse impacts of lipid peroxidation using Ag-BSEPS, recommending that Ag-BSEPS assumes a vital role in the fixing of lipid impairment led by TAA-initiated detriment of the liver. Additionally, Ag-BSEPS administration $(p<$ $0.05)$ significantly prevented the curtailment in antioxidant levels. These antioxidant enzymes act with each other at various destinations in the metabolic pathways including free radicals (Trush et al. 1982; Singh et al. 2016).

Angiogenesis plays a crucial role in chronic inflammation. Under the conditions of accumulation of inflammatory leaks, and the development of fibrosis, the tissues will resist blood flow and oxygen delivery, leading to hypoxia. Subsequently, the transformation of the vasculature occurs in the increased regulation of the factors responsible for the formation of blood vessels and neovessels (Carmeliet and Jain 2000; Pugh and Ratcliffe 2003). The VEGF and nitric oxide (NO) are widely accepted factors for enhancing and promoting blood vessel formation (Zhang et al. 2003).

The end phase of cell degeneration is represented in apoptotic bodies or necrotic hepatocytes. Thus, apoptosis is a process in which single cells eradicated by sequential serial fragmentation by enzyme-induced DNA without cell membrane injury, in contrast to necrosis, where the DNA is denaturized haphazardly together with alternative cellular proteins (Cummings et al. 1997). In the current study, the biopsy specimens of the TAA group demonstrated a significant increase in DNA fragmentation compared to the control and Ag-BSEPS-treated groups.

\section{Conclusion}

The current study demonstrated that nano-Ag-BSEPS markedly declined liver fibrosis in vivo. Ag-BSEPS decreased PCIII accruement regulated the balance between

Table 3 The effect of Ag-BSEPS on some pro and anti-inflammatory cytokines in liver of rats

\begin{tabular}{llllll}
\hline Groups & TNF- $\mathrm{a}(\mathrm{pg} / \mathrm{mg})$ & $\mathrm{INF}-\gamma(\mathrm{pg} / \mathrm{ml})$ & $\mathrm{IL}-6(\mathrm{pg} / \mathrm{mg})$ & $\mathrm{IL}-1 \beta(\mathrm{pg} / \mathrm{mg})$ & $\mathrm{IL}-10(\mathrm{pg} / \mathrm{mg})$ \\
\hline Control (GI) & $42.55 \pm 3.65^{\mathrm{b}}$ & $27.40 \pm 1.76^{\mathrm{a}}$ & $5.12 \pm 0.43^{\mathrm{b}}$ & $8.79 \pm 0.82^{\mathrm{b}}$ & $7.73 \pm 0.69^{\mathrm{a}}$ \\
TAA (GII) & $187.45 \pm 9.62^{\mathrm{a}}$ & $8.18 \pm 0.89^{\mathrm{b}}$ & $13.06 \pm 1.27^{\mathrm{a}}$ & $35.56 \pm 1.57^{\mathrm{a}}$ & $3.65 \pm 0.05^{\mathrm{b}}$ \\
Ag-BSEPS (GIII) & $47.02 \pm 2.78^{\mathrm{b}}$ & $31.70 \pm 2.66^{\mathrm{a}}$ & $5.80 \pm 0.78^{\mathrm{b}}$ & $10.42 \pm 0.76^{\mathrm{b}}$ & $8.01 \pm 0.77^{\mathrm{a}}$ \\
TAA + Ag-BSEPS (GIV) & $53.13 \pm 6.11^{\mathrm{b}}$ & $27.95 \pm 2.87^{\mathrm{a}}$ & $6.31 \pm 0.59^{\mathrm{b}}$ & $14.16 \pm 1.23^{\mathrm{b}}$ & $8.35 \pm 0.62^{\mathrm{a}}$ \\
\hline
\end{tabular}

Values are expressed as mean \pm SE. Different superscript letters in the same row indicate significant differences at $p<0.05$. 

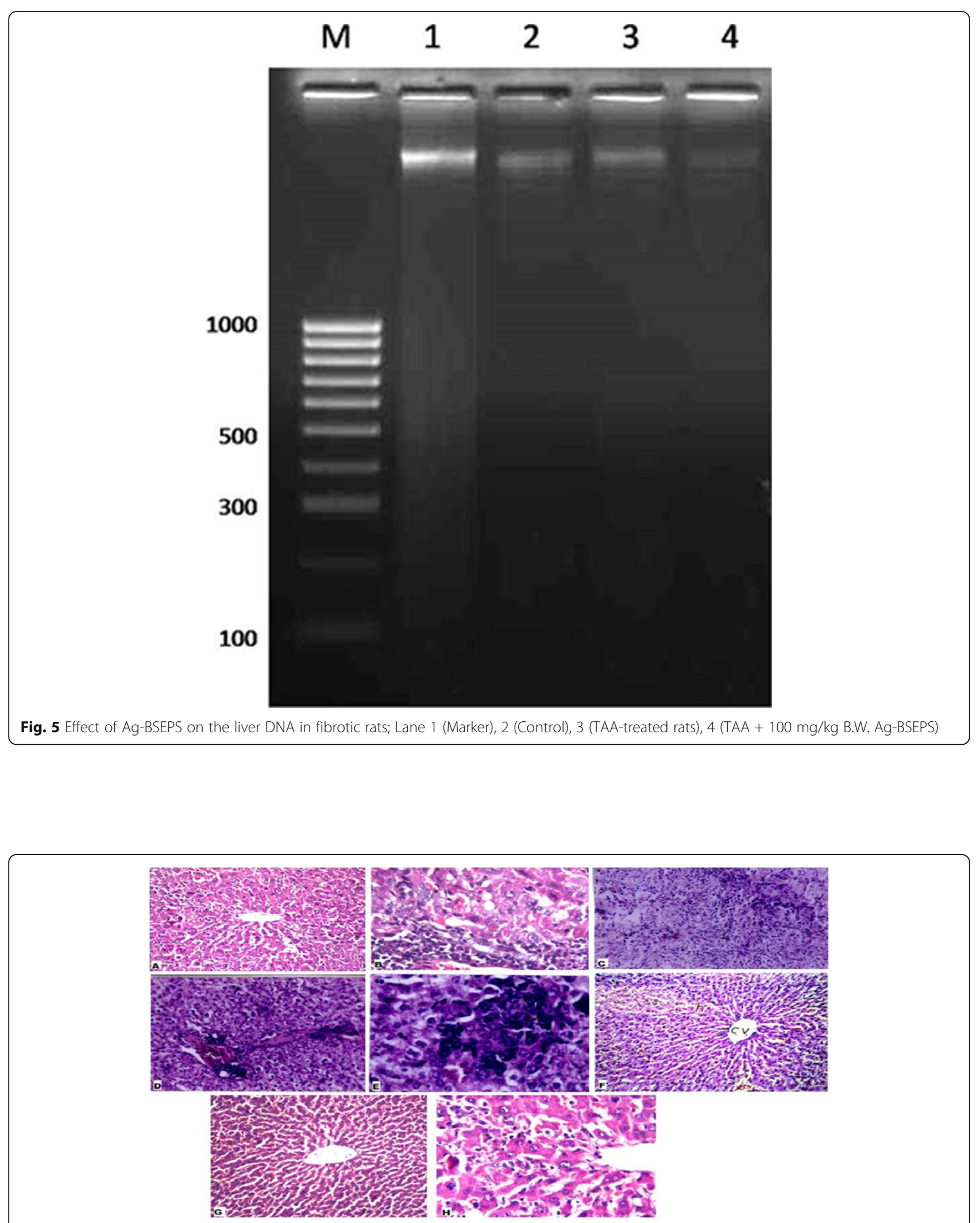

Fig. 6 Photomicrographs of rat livers. a Normal group. b-e TAA group, with the massive fibrosis, the fatty change was detected in the hepatocytes at the centrilobular area of the parenchyma surrounding the central vein. $\mathbf{f}-\mathbf{h}$ Nano-Ag-BSEPS group, showed regression in periductal fibrosis and degradation of hepatocytes 
Table 4 Histopathological changes in the liver of rats exposed to TAA and the treatment effect of Ag-BSEPS, based on scoring severity of injury

\begin{tabular}{lllll}
\hline Observation & Control (GI) & TAA (GII) & Ag-BSEPS (GIII) & TAA + Ag-BSEPS (GIV) \\
\hline Focal area in the degenerated hepatocytes & - & ++++ & - & + \\
Congestion in the blood vessels & - & ++++ & - & - \\
Inflammatory cells & - & ++++ & ++ & - \\
Necrosis & - & +++ & - \\
Massive fibrosis & - & +++ & - & - \\
Hepatocytes degeneration & & +++ & - & - \\
\hline
\end{tabular}

Normal $(-)$, minimal $(+)$, mild $(++)$, severe $(++++)$

collagen synthesis and its breakdown consequently, preventing the destruction or fibrosis of the liver. The antifibrotic effect of Ag-BSEPS may affect inflammation, inhibiting the oxidative stress concomitant lipid peroxidation which are implicated in the genesis of liver fibrosis and modulation of TGF- $\beta$. Therefore, Ag-BSEPS conspicuously increased GSH-PX, SOD, and CAT quantities. The current outcomes propose that Ag-BSEPS is a prospective agent for the cure of liver fibrosis due to simple technology to produce drug-containing nanoparticles of a silver core coated with BSEPS having a stable structure without using any organic solvent or surfactant.

\section{Abbreviations}

$\mathrm{AgNO}_{3}$ : Silver nitrate; ALP: Alkaline phosphatase; ALT: Alanine transaminase; AST: Aspartate aminotransferase; CAT: Catalase; EB: Ethidium bromide; EDTA: Ethylene diamine tetra-acetic; EPS: Exopolysaccharides; FT-IR: Fouriertransform infrared; GGT: Gamma-glutamyl transferase; GSH-PX: Glutathione peroxidase; $\mathrm{H}_{2} \mathrm{O}_{2}$ : Hydrogen peroxide; HPLC: High-performance liquid chromatography; IL 10: Interleukin 10; IL1ß: Interleukin 1 beta; IL6: Interleukin 6; INF- $\gamma$ : Interferon gamma; NADPH: Nicotinamide adenine dinucleotide phosphate; PCIII: Type III pro-collagen; RES: Reticuloendothelial system; SEM: Scanning electron microscope; SOD: Superoxide dismutase; TAA: Thioacetamide; TBARS: Thiobarbituric acid reactive substances; TEM: Transmission electron microscope; TGF- $\beta 1$ : Transforming growth factor beta 1; VEGF: Vascular endothelial growth factor

\section{Acknowledgements}

The authors are grateful to Dr. Adel M. Bakeer Kholoussy, Professor of Pathology, Faculty of Veterinary Medicine, Cairo University for helping in the examination of the histopathological slides and for his valuable comments.

\section{Authors' contributions}

All authors contributed in this work and in writing the manuscript. All authors read and approved the final manuscript.

\section{Funding}

There is no funding for this personal research.

\section{Availability of data and materials}

The datasets used and/or analyzed during the current study are available from the corresponding author on reasonable request.

\section{Ethics approval and consent to participate}

The manuscript does not contain studies involving human participation. The study protocol was approved by members of The Research Ethics Committee, of the National Research Centre in Egypt.

\section{Consent for publication}

Not applicable

\section{Competing interests}

The authors declare that they have no competing interests.

\section{Author details}

'Department of Microbial Biotechnology, National Research Centre, 33 Bohouth St., Dokki, Giza 12311, Egypt. ²Department of Radioisotopes, Atomic Energy Authority, Nuclear Research Centre, Cairo, Egypt. ${ }^{3}$ Department of Ceramics, Refractories and Building Materials, National Research Centre, 33 Bohouth St., Dokki, Giza 12311, Egypt.

Received: 21 June 2019 Accepted: 26 November 2019

Published online: 11 December 2019

\section{References}

Abdelazim SA, Darwish HA, Ali SA, Rizk MZ, Kadry MO (2015) Potential antifibrotic and angiostatic impact of idebenone, carnosine and vitamin $E$ in nano-sized titanium dioxide-induced liver injury. Cell Physiol Biochem 35:2402-2411

Al-Attar AM, Al-Rethea HA (2017) Chemoprotective effect of omega-3 fatty acids on thioacetamide induced hepatic fibrosis in male rats. Saudi J Biol Sci 24(4): 956-965

Allene J, Wilham CA (1950) Periodate oxidation of dextran. Journal of American Chemical Society 72:2655-2657

Anthony PP, Ishak KG, Nayak NC, Poulsen HE, Scheuer P, Sobinm LH (1978) The morphology of cirrhosis. J Clin Pathol 31:395-414

Banchroft JD, Stevens A, Turner DR (1996) Theory and practice of histological techniques, Fourth edn. Churchil Livingstone, New York, London, San Francisco, Tokyo

Bataller R, Brenner DA (2005) Liver fibrosis. J Clin Invest 115:209-218

Carmeliet P, Jain RK (2000) Angiogenesis in cancer and other diseases. Nature 407(6801):249-257

Chobert MN, Couchie D, Fourcot F, Zafrani ES, Laperche Y, Mavier P, Brouillet A (2012) Liver precursor cells increase hepatic fibrosis induced by chronic carbon tetrachloride intoxication in rats. Lab Invest 92(1):135-150

Chu CJ, Chang CC, Wang TF, Lee FY, Chang FY, Chen YC et al (2006) Detrimental effects of nitric oxide inhibition on hepatic encephalopathy in rats with thioacetamide-induced fulminant hepatic failure: role of nitric oxide synthase isoforms. J Gastroenterol Hepatol 21:1194-1199

Cummings CM, Winterford CM, Walker NI (1997) Apoptosis. Am J Surg Pathol 21: 88-101

Czechowska G, Celinski K, Korolczuk A, Wojcicka GJ, Dudka J, Bojarska A, Reiter R (2015) Protective effects of melatonin against thioacetamide-induced liver fibrosis in rats. J Physiol Pharmacol 66(4):567-579

Friedman SL (2008) Hepatic stellate cells: protean, multifunctional, and enigmatic cells of the liver. Physiol Rev 88:125-172

Ghoneim MAM, Hassan Al, Mahmoud MG, Asker MS (2016) Effect of polysaccharide from Bacillus subtilis sp. on cardiovascular diseases and atherogenic indices in diabetic rats. BMC Complement Altern Med 16:112

Giannitrapani L, Soresi M, Bondi ML, Montalto G, Cervello M (2014) Nanotechnology applications for the therapy of liver fibrosis. World J Gastroenterol 20(23):7242-7251

Guerra RR, Trotta MR, Aloia TPA, Dagli MLZ, Hernandez-Blazquez FJ (2010) A novel chronic cirrhosis TAA-induced model in rats. Braz J Vet Pathol 3(1):9-16

Gutiérrez D, Delgado S, Vázquez-Sánchez D, Martínez B, Cabo ML, Rodríguez A et al (2012) Incidence of Staphylococcus aureus and analysis of associated 
bacterial communities on food industry surfaces. Appl Environ Microbiol 78 $8547-8554$

Huiru Z, Heindel ND (1991) Determination of degree of substitution of formyl groups in polyaldehyde dextran by the hydroxylamine hydrochloride method. Pharmaceutical Research 8:400-402

ILAR (Institute of Laboratory Animal Resources) (1985) Guide for the Care and Use of Laboratory Animals. NIH Publication No. 86-23 (revised 1985). Prepared by the Committee on Care and Use of Laboratory Animals of theNational Academy Press, Washington, D.C.

Iravani S, Korbekandi H, Mirmohammadi SV, Zolfaghari B (2014) Synthesis of silver nanoparticles: chemical, physical and biological methods. Res Pharm Sci 9(6): 385-406

Ismail MH, Pinzani M (2009) Reversal of liver fibrosis. Saudi J Gastroenterol 15(1): 72-79

Kakkar R, Kaira J, Mantha SV, Prasad K (1999) Lipid peroxidation and activity of antioxidant enzymes in diabetic rats. Mol Cell Biochem 151:113-119

Kawai Y, Satoh T, Hibi D, Ohno Y, Kohda Y, Miura K, Gemba M (2009) The effect of antioxidant on development of fibrosis by cisplatin in rats. J Pharmacol Sci 111(4):433-439

Nakajima M, Iwata K, Yamamoto T, Funae Y, Yoshida T, Kuroiwa Y (1998) Nicotine metabolism in liver microsomes from rats with acute hepatitis or cirrhosis. Drug Metab. Dispos 26:36-41

Ohkawa H, Ohishi N, Yagi K (1979) Assay of lipid peroxidation in animal tissues by thiobarbituric acid reaction. Anal Biochem 95:351-358

Pugh CW, Ratcliffe PJ (2003) Regulation of angiogenesis by hypoxia: role of the HIF system. Nature Medicine 9(6):677-684

Rotruck JT, Pope AL, Ganther HE, Swanson AB, Hafeman DG, Hoekstra WG (1973) Selenium: biochemical role as a component of glutathione peroxidase. Science 179(4073):588-590

Ruocco N, Costantini S, Guariniello S, Costantini M (2016) Polysaccharides from the marine environment with pharmacological cosmeceutical and nutraceutical potential. Molecules 21:551-566

Sathupunya M, Gulari E, Jamieson A, Wongkasemjit S (2004) Microwave-assisted preparation of zeolite $\mathrm{K}-\mathrm{H}$ from alumatrane and silatrane. Micropor Mesopor Mat 69(3):157-164

Sathupunya M, Gulari E, Wongkasemjit S (2003) Na-A (LTA) zeolite synthesis directly from alumatrane and silatrane by sol-gel microwave techniques. J Eur Ceram Soc 23(8):1293-1303

Singh D, Cho WC, Upadhyay G (2016) Drug-induced liver toxicity and prevention by herbal antioxidants: an overview. Front Physiol 6:363-380

Sinha AK (1972) Colorimetric assay of catalase. Anal Biochem 47(2):389-394

Trush ME, Mimnaugh EG, Ginsburg E, Gram TE (1982) Studies on the in vitro interaction of mitomycin C, nitrofurantoin and paraquat with pulmonary microsomes. Stimulation of reactive oxygen-dependent lipid peroxidation. Biochem Pharmacol 31:805-814

Wenshan LV, Booz GW, Wang Y, Fan F, Roman RJ (2018) Inflammation and renal fibrosis: recent developments on key signaling molecules as potential therapeutic targets. Eur J Pharmacol 820:65-76

Werther K, Christensen IJ, Nielsen HJ (2002) Prognostic impact of matched preoperative plasma and serum VEGF in patients with primary colorectal carcinoma. Br J Cancer 86(3):417-423

Yanguas SC, Cogliati B, Willebrords J, Maes M, Colle I, den Bossche B, de Oliveira CM, Andraus W, Alves VAF, Leclercq I, Vinken M (2016) Experimental models of liver fibrosis. Arch Toxicol 90(5):1025-102

Ying M, Li N, Yang C, Yang X (2005) One-step synthesis of amino-dextranprotected gold and silver nanoparticles and its application in biosensors. Analytical and Bioanalytical Chemistry 382:1044-1048

Youssef HF, Ibrahim D, Komarneni S (2008) Microwave-assisted versus conventional hydrothermal synthesis of zeolite A from metakaolinite. Micropor Mesopor Mat 115:527-534

Zhang L, Yang N, Park JW, Katsaros D, Fracchioli S, Cao G, O'Brien-Jenkins A Randall TC, Rubin SC, Coukos G (2003) Tumor-derived vascular endothelial growth factor up-regulates angiopoietin-2 in host endothelium and destabilizes host vasculature, supporting angiogenesis in ovarian cancer. Cancer Res 63(12):3403-3412

\section{Publisher's Note}

Springer Nature remains neutral with regard to jurisdictional claims in published maps and institutional affiliations.

\section{Submit your manuscript to a SpringerOpen ${ }^{\odot}$ journal and benefit from:}

- Convenient online submission

- Rigorous peer review

- Open access: articles freely available online

- High visibility within the field

- Retaining the copyright to your article

Submit your next manuscript at $\boldsymbol{\nabla}$ springeropen.com 